\title{
Micromorphology and anatomy of fruits of Angelica archangelica L. (Apiaceae) and their intraspecific differentiation
}

\author{
ANNA FORYCKA ${ }^{1 *}$, MARIA MOROZOWSKA ${ }^{2 \circledast}$
}

\author{
${ }^{1}$ Department of Botany, Breeding and Agricultural Technology of Medicinal Plants \\ Institute of Natural Fibres and Medicinal Plants \\ Kolejowa 2 \\ 62-064 Plewiska, Poland \\ ${ }^{2}$ Department of Botany \\ Poznań University of Life Sciences \\ Wojska Polskiego $71 \mathrm{C}$ \\ 60-625 Poznań, Poland \\ *corresponding author: e-mail: anna.forycka@iwnirz.pl
}

\section{Summary}

Introduction: Angelica archangelica L. (Apiaceae) has a long history of use as a vegetable and medicinal plant. According to the European Pharmacopoeia, the angelica root (Angelica radix) of only one of the subspecies - Angelica archangelica subsp. archangelica (formerly known as Archangelica officinalis) - is used as a source of plant material with documented medicinal properties. Within this species, there are two subspecies that are difficult to classify unambiguously: subsp. archangelica and subsp. litoralis.

Objective: The aim of this study was to provide a micromorphological and anatomical description of fruits of $A$. archangelica and identify new diagnostic characters useful in subspecies identification.

Methods: A comparative analysis of the sculpture and internal structure of fruits of the distinguished A. archangelica taxa was conducted, using scanning electron microscopy (SEM).

Results: Based on the taxonomic characters in the Apiaceae family, micromorphological and anatomical characteristics of $A$. archangelica fruits were prepared. Some of the investigated characters, e.g. verrucose sculpture of the oil duct surface and the presence of hooked hairs, exhibited intraspecific differences. Among the anatomical characters, the variation was related to the number and size of the paraendocarpic oil ducts as well as to the thickness of dorsal and commissural mesocarp.

Conclusion: SEM examination of fruits of $A$. archangelica provided a detailed description of their sculptures and several micromorphological and anatomical characters of potential diagnostic value. 
Key words: Angelica, Angelica archangelica, subsp. archangelica, subsp. litoralis, fruit micromorphology, fruit anatomy, SEM

Słowa kluczowe: Angelica, Angelica archangelica, subsp. archangelica, subsp. litoralis, mikromorfologia owoców, anatomia owoców, SEM

\section{INTRODUCTION}

Correct identification of taxa is particularly important in medicinal plants due to their characteristic chemical composition responsible for specific biological properties. Angelica archangelica L. is a plant of the Apiaceae family with a long history of use as a vegetable and medicinal raw material [1]. It belongs to the complex genus Angelica that has been subjected to taxonomic revision many times [2-5].

According to current taxonomic approach, two subspecies of $A$. archangelica are distinguished, previously treated as two separate species: subsp. archangelica (Aaa) (formerly Archangelica officinalis Hoffm.) and subsp. litoralis (Fies) Thell. (Aal) (formerly Archangelica litoralis Fries), which are found in different habitats - in mountainous areas of North and East Europe, Greenland, and Northwestern Asia as well as in lowlands - primarily in river valleys of the Nordic countries and along Baltic Sea coasts [6-9]. Due to the cultivation of herbal crops of garden angelica and its ability to quickly spread along river valleys, this plant now occupies new areas [10-14]. Formerly encountered in different regions, nowadays both taxa can occur alongside each other $[15,16]$.

A review of the literature regarding the content of the most important active compounds in A. archangelica plant materials confirms the occurrence of large chemical variations within this species [17]. However, the only source of plant material is the angelica root (Angelica radix) of subsp. archangelica Archangelica officinalis, with documented medicinal properties [18].

The fruit characters are usually used in taxonomic classification of the extremely polymorphic Apiaceae family due to their conservative nature. In practice, however, morphological evaluation of fruits does not give a clear answer as regards the discrimination between angelica taxa, especially outside the place of their original occurrence $[19,20]$.

The micromorphological characters of fruits and their anatomical structure are frequently a valuable source of information providing new data for taxonomic identification and revision in the family Apiaceae [21, 22]. Numerous studies dealing with different genera and families confirm the taxonomic importance of these characters and prove that the variation in primary and secondary surface sculpture as well as in the internal structure of fruits of specific species may have systematic consequences [23-30]. It turns out that the characteristics of epidermis are affected by environmental conditions in which a plant grows to a relatively low extent, predominantly being under strong genetic control [31, 32]. In plants, the co-dependence of morphological and anatomical characters is frequently determined in line with the vector of diaspore dispersal (e.g. through wind, water, or animals) [21].

Researchers' experience demonstrates that many micromorphological characters often have a high taxonomic value in characterizing the lowest taxonomic categories. They include the following, among others: typical cell shapes, types of cuticular striations, and the presence and type of epicuticular waxes [31].

To deepen the present study, scanning electron microscopy (SEM) was employed, which can be used to track the surface microsculpture. The SEM investigations are also a good source of information on the internal structure of fruits because the outline of the fruit and endosperm, the location of secretory ducts, the shape and size of cells, and the structure of cell walls are visible in cross-section and easy to observe [22].

This research investigated for the first time the fruit characters in the distinguished $A$. archangelica taxa using SEM.

The aim of this study was to provide micromorphological and anatomical characterization of angelica fruits and to identify characters of potential diagnostic value.

\section{MATERIAL AND METHODS}

\section{Plant material}

This study used material collected from plants growing in the wild. To evaluate the variation in the characters of angelica fruits, two population types occurring in Poland were compared: (1) populations found in their natural area of occurrence in mountainous regions; (2) populations found in their original area of occurrence in the coastal zone. Ten mature fruits randomly selected from the mountainous populations, 
treated as A. archangelica subsp. archangelica (Aaa), and from the coastal populations, considered to be A. archangelica subsp. litoralis (Aal), were studied. The populations of Aaa were located on the shores of mountain lakes or streams: Karkonosze - Mały Śnieżny Kocioł; Tatra Mountains - Czarny Staw, Dolina Pięciu Stawów Polskich, Kobylarzowy Żleb, Chuda Turnia. The Aal fruits came from populations found in river valleys or on the shores of lakes: Pomerania - Święta, Zagórze, Dziwnów, Dźwirzyno, Dąbki, Świbno, Rybina. In Poland, A. archangelica is a protected species. The fruits were collected in 2013-2014 in accordance with the permission of the Ministry of the Environment, the Karkonosze National Park, the Tatra National Park and the Regional Directorates for Environmental Protection.

Fully developed and mature fruits found on an umbellule in the primary umbel, which were randomly selected from the central region of the umbel, were subjected to carpological analysis.

\section{SEM examination}

The microstructural characters of the surface of the fruits and their cross-sections were analyzed using scanning electron microscopy (SEM). Using a scalpel, $0.5 \mathrm{~mm}$ thick cross-section pieces of the fruits were cut in the middle of their length. The fruits and their cuttings, as hard objects, did not require dehydration and fixation [33] and after having been mounted on a carbon tab on a standard aluminum stub, they were sputter coated with gold. A Philips FEM 515 scanning electron microscope was used for SEM examination and photographic documentation, which was carried out at the Electron Microscopy Laboratory at the Faculty of Biology, the Adam Mickiewicz University in Poznań. The microstructural characters were observed on the dorsal and commissural surface of the fruits. The surface cell pattern, surface sculpture, and the anatomical characters of the fruits were described according to the terminology adopted in the following SEM studies: Kljuykov et al. [34], Pimenov and Ostroumova [35], Klimko et al. [36], Liu et al. [37], Kljujkov et al. [38], Barthlott et al. [39], Barthlott [31]. After the initial examination of the fruits, the characters shown in table 1 were selected for analysis of the micromorphological and anatomical structure.

Ethical approval: The conducted research is not related to either human or animal use.

Table 1.

Micromorphological and anatomical characters of the fruits analyzed in SEM

\begin{tabular}{lll}
\hline No. & \multicolumn{1}{c}{ Micromorphological features } & \multicolumn{1}{c}{ Anatomical features } \\
\hline 1 & Cellular pattern; arrangement of hairs/stomata & Mericarp outline in transverse section \\
\hline 2 & Outline of cells & Shape of dorsal and marginal ribs \\
\hline 3 & Anticlinal walls & Exocarp - shape of cells \\
\hline 4 & Relief of anticlinal walls boundary & Mesocarp - lignification of parenchyma cells \\
\hline 5 & Curvature of outer periclinal cell wall & Number of mesocarp cells between vascular bundles of dorsal rib and endocarp \\
\hline 6 & Relief of the outer periclinal cell wall & Number of mesocarp cells between vascular bundles of marginal rib and endocarp \\
\hline 7 & Epicuticular waxes on dorsal and commissural & Thickness of dorsal mesocarp [ $\mu \mathrm{m}]$ \\
\hline 8 & side of mericarp and wing surface & Thickness of commissural mesocarp $[\mu \mathrm{m}]$ \\
\hline 9 & & Vascular bundle arrangement \\
\hline 10 & Number of rib secretory ducts \\
\hline 11 & Endocarp - shape of cells \\
\hline 12 & Number of paraendocarpic ducts (vittae) \\
\hline 13 & Vittae arrangement \\
\hline 14 & Shape of paraendocarpic ducts \\
\hline 15 & Width of paraendocarpic ducts $[\mu \mathrm{m}](3$ randomly selected ducts) \\
\hline 16 & Height of paraendocarpic ducts $[\mu \mathrm{m}](3$ randomly selected ducts) \\
\hline 17 & Endosperm - shape of cells \\
\hline & Presence and arrangement of crystals \\
\hline 18 & & \\
\hline
\end{tabular}




\section{RESULTS}

The angelica fruit is a schizocarp consisting of two mericarps, attached on a split stalk called carpophore. The flat side at the point of contact of the mericaps is termed as the commissural side, while the convex dorsal side, with three dorsal ribs and two marginal ribs developed as wings, is opposite to it.

\section{Micromorphological characteristics}

The surface of the angelica fruits was undulating at many places, while the cell outline was frequently invisible. On the dorsal surface of the mericarps, there was a reticulate cell pattern, not always well outlined due to the strong striation of the cuticle. In the middle part of the fruit wing, where the cell pattern was best visible, quadrangular to hexagonal isodiametric cells were observed, having straight anticlinal walls and flat periclinal walls with strongly striated cuticle (fig. 1A, 2A). At the margin of the upper and lower surface of the wing, a more conspicuous reticulate cell pattern could be seen. The cells were polygonal, slightly elongated, with raised anticlinal walls and concave periclinal walls covered by striated cuticle with striations parallel to the long axis of the fruit (fig. 1B, 2B). On the commissural surface of the fruits, a reticulate cell pattern was also observed, composed of polygonal equilateral cells with straight, but diverse anticlinal walls. Near the fusion part of the mericarp and on its edges, the walls were clearly raised, whereas in the other parts of the fruit they were flat or slightly channeled. The periclinal walls were flat or slightly concave with strongly striated cuticle (fig. 1E, 2G). On the commissural surface of the fruit of Aaa, numerous projections were additionally found in the form of little excrescences (fig. 1F).

Stomata occurred on the dorsal and commissural surface of the fruit, in greatest numbers on the surface of the wing on its both sides. These were anomocytic stomata - surrounded by a variable number of radially arranged subsidiary cells and with strongly striated cuticle (fig. 1C, 2C). In the typical subspecies Aaa, the stoma length, measured along the long diameter of the pore, ranged from 12.25 to $18.83 \mu \mathrm{m}$, while in the coastal subspecies Aal from 16.23 to $19.36 \mu \mathrm{m}$.

In both subspecies, hairs were found on the dorsal and commissural surface of the mericarps. These were non-glandular trichomes, triangular in outline, laterally compressed, sharply narrowing to a pointed or rounded tip, with verrucose cuticular microornamentation (fig. 1G, 1H, 2F). Straight hairs were observed on the fruits of both taxa (fig. $1 \mathrm{H}, 2 \mathrm{~F}$ ), whereas in Aal hooked hairs were additionally found (fig. $2 \mathrm{H}$ ). Moreover, conical hairs with a broad, round or oval base and a narrow blunt apex as well as with verrucose microornamentation were present in both taxa (fig. 1I, 2I). The hairs were most numerous and unevenly distributed on the commissural surface of the fruits. The observed hairs had a varying height from 15.00 to $45.39 \mu \mathrm{m}$ in Aaa and from 21.15 to $36.86 \mu \mathrm{m}$ in Aal.

On both surfaces of the fruits, there was an epicuticular wax film with unevenly distributed formations in the form of platelets and plates (fig. 1D, $2 \mathrm{D}, 2 \mathrm{E})$. Epicuticular waxes were observed more frequently on the dorsal surface of the fruit, usually close to the stomata (fig. 2C). Single wax platelets were also visible in the stomata.

On the surface of the endocarp surrounding the seed, there were raised, cylindrical paraendocarpic secretory ducts with reticulate microornamentation (fig. 1J, 1K, 2J, 2K). They were distributed regularly, parallel to the long axis of the fruit. Most of them ran along the entire length of the seed. The mesocarp cells on the surface of the oil ducts were quadrangular or pentagonal, with straight raised anticlinal walls and flat periclinal walls. The surface of the periclinal cell walls on the oil ducts in the fruits of Aaa was smooth (fig. $1 \mathrm{~K}$ ), while in the fruits of Aal it was verrucose (fig. $2 \mathrm{~K}, 2 \mathrm{~L}$ ). On the oil duct surface, sharp-pointed needle-like crystals were found in single cells in both taxa (fig. 1L).

\section{Anatomical characteristics}

In $A$. archangelica, the mature mericarp is slightly dorsally compressed. In cross-section, two layers of the pericarp are visible - the outer one composed of several-layered exo- and mesocarp and the inner one detached from it, a single layer of endocarp cells surrounding the seed. Between them, there is an airfilled cavity (fig. 3A, 4A).

In the typical subspecies Aaa, the dorsal ribs most frequently had an outline similar to a triangle with an extended tip in cross-section (fig. 3A), while those found in the coastal subspecies Aal resembled a pentagon (fig. 4A). The marginal ribs were stretched and shaded, having a shape similar to a wing of varying width; they were generally more conspicuous in Aal than in Aaa. 

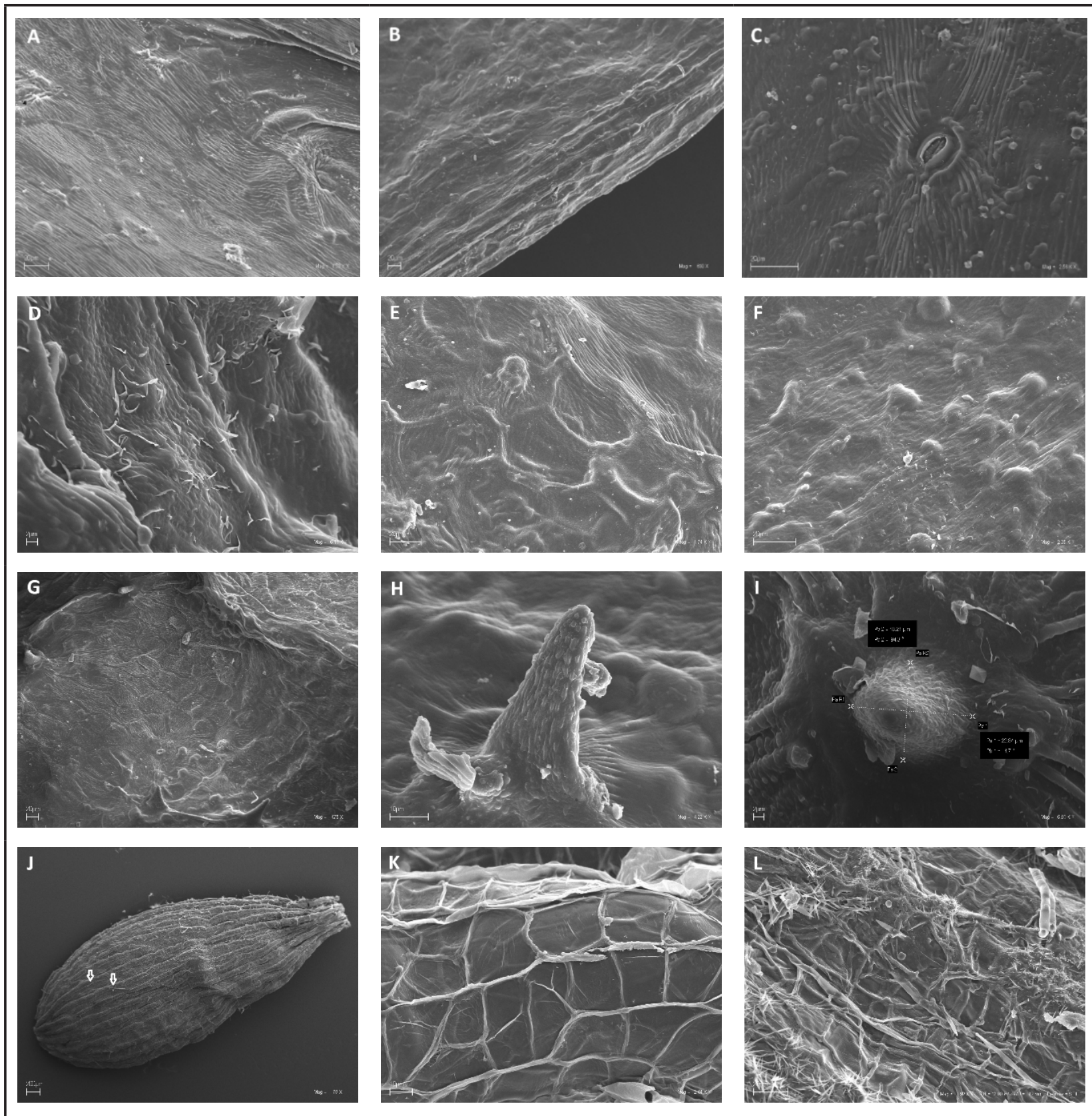

Figure 1.

SEM micrographs of fruits in Angelica archangelica subsp. archangelica: (A-E) wing: (A) dorsal surface of the wing: reticulate cell pattern, cells polygonal, anticlinal walls straight, sunken and periclinal wall surface flat, cuticle striated; (B) dorsal surface: reticulate cell pattern at the edge of the wing; (C) stoma on the dorsal surface of the wing surrounded by cells with distinctly striated cuticle; (D) commissural surface of the wing with epicuticular wax platelets; (E) commissural surface of the wing - reticulate cell pattern, cells polygonal, anticlinal walls straight, raised or sunken and periclinal wall surface flat or slightly concave, cuticle striated; (F-I) commissural surface of the mericarp: (F) parallel cuticular striations and little excrescences; (G) hairs and verrucae; (H) laterally compressed hair with verrucose cuticular microornamentation; (I) conical hair with a broad base and verrucose microornamentation; (J-L) dorsal surface of the inner part of the fruit: (J) seed with the outline of secretory ducts (arrows); (K) reticulate cell pattern of the mesocarp on the oil duct surface - smooth surface of the periclinal walls; (L) sharp-pointed needle-like crystals on the oil duct surface 

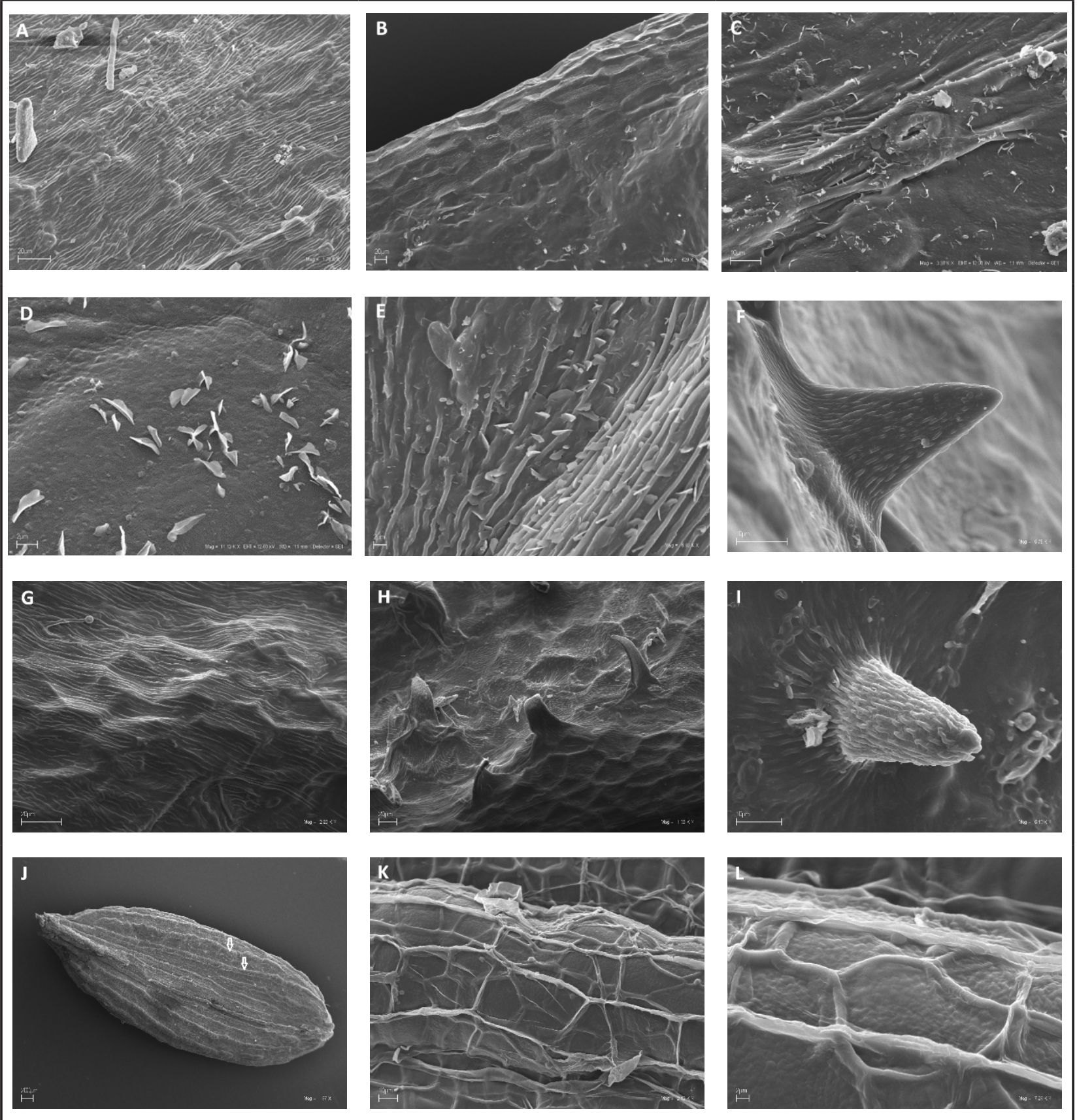

Figure 2.

SEM micrographs of fruits in Angelica archangelica subsp. litoralis: (A-E) wing: (A) dorsal surface of the wing: reticulate cell pattern, cells polygonal, anticlinal walls sunken, straight and flat periclinal walls, cuticle striated; (B) dorsal surface: reticulate cell pattern at the edge of the wing; (C) dorsal surface of the wing: stoma surrounded by cells with striated cuticle and epicuticular waxes; (D) dorsal surface with epicuticular wax platelets; (E) wax plates on the striation near a stoma on the dorsal surface; (F) dorsal surface of the mericarp: non-glandular, laterally compressed hair with verrucose-striated microornamentation; (G-I) commissural surface of the mericarp: $(G)$ reticulate cell pattern, cells polygonal, straight, raised anticlinal walls and flat or concave periclinal walls, cuticle striated; $(\mathrm{H})$ hairs on the commissural surface - laterally compressed, hooked; (I) conical hair with verrucose microornamentation on the commissural surface; (J-L) commissural surface of the inner part of the fruit: (J) seed with the oil duct outline (arrows); (K) reticulate cell pattern of the mesocarp on the oil duct surface - verrucose surface of the periclinal walls; (L) close-up on the periclinal walls with verrucose surface 
The exocarp (epidermis) is made up of a single layer of small epidermal cells, rectangular in crosssection, elongated along the fruit axis, with slightly thickened outer walls (fig. 3B, 3C, 4B, 4C). Under the epidermis, there is several-layered mesocarp, mostly composed of lignified parenchymatic cells with slightly thickened secondary walls having very numerous slit-like or rounded pits and small intercellular cavities (fig. 3C, 3D, 4C, 4D). Depending on its location in the fruit, the mesocarp consisted of 2-4 cell layers situated under the dorsal rib and of 3-5 cell layers located between the lateral rib and the endocarp. The thickness of the dorsal and commissural mesocarp in the fruits of Aaa ranged 98.00-177.70 $\mu \mathrm{m}$ and $126.80-189.90 \mu \mathrm{m}$, respectively. In Aal, the same measurements were 38.30$128.40 \mu \mathrm{m}$ and $73.90-148.90 \mu \mathrm{m}$ (fig. 3B, 4B).

Vascular bundles and associated schizogenous secretory canals were found in each rib. The vascular bundles in the dorsal and marginal ribs formed an arch made up of several bundles, while in the marginal ribs small separated bundles were additionally encountered. In the dorsal ribs, one or two small intrajugal oil ducts were usually visible (fig. 3F, 4F, $4 \mathrm{G})$, whereas in the marginal ribs - most frequently two such ducts (fig. 3G).
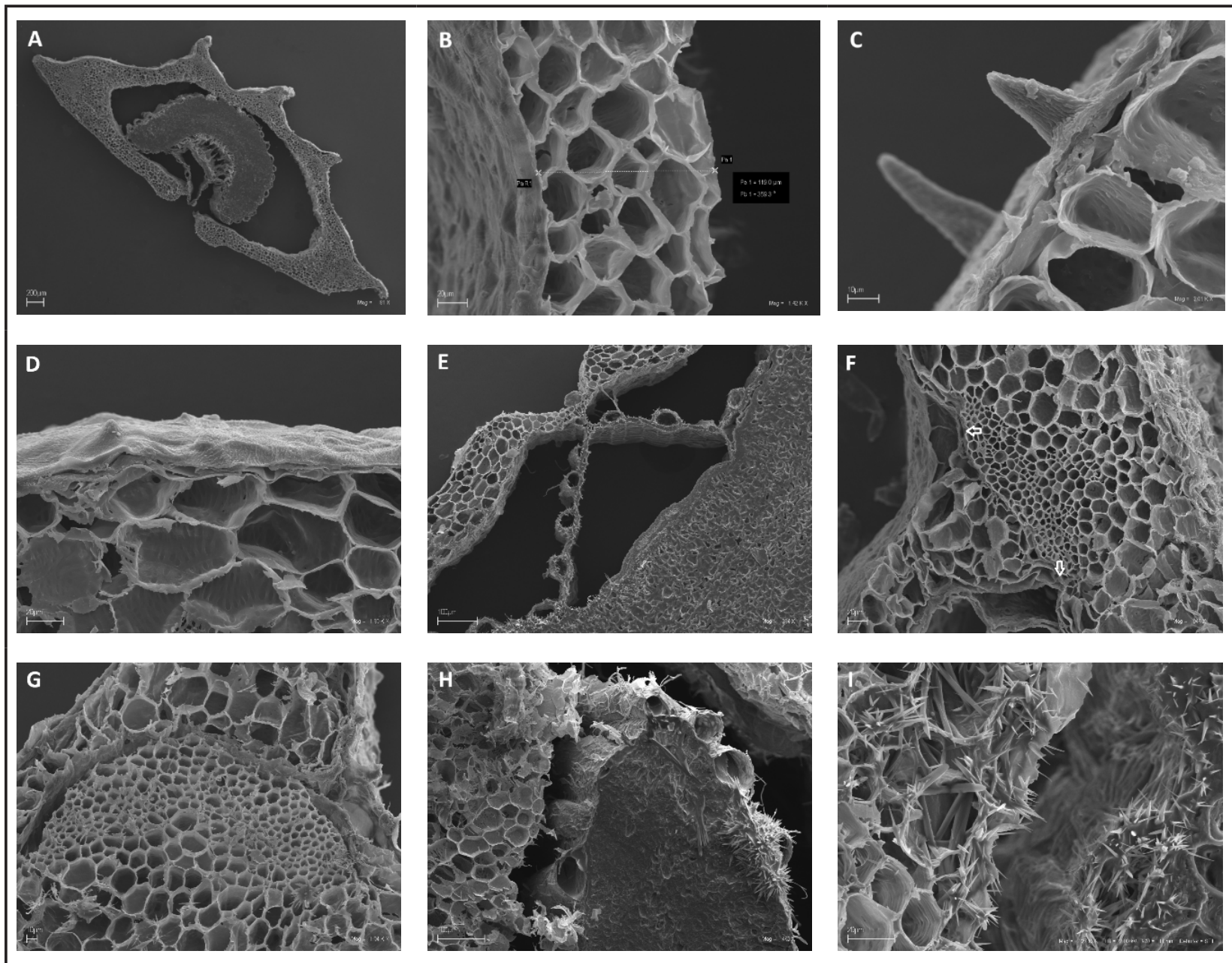

Figure 3.

SEM micrographs of fruits in Angelica archangelica subsp. archangelica (A) Cross-section of the mericarp: exo- and mesocarp separated by an air cavity from the seed with endocarp; (B) cross-section through the mesocarp nd exocarp in the depression between the dorsal ribs; (C) cross-section of the pericarp: parenchyma cells of the mesocarp and hairs on the dorsal surface of epidermis; (D) parenchyma cells of the mesocarp with pitted walls; (E) cross-sectional detail with the visible endocarp and oil ducts adhering to it and separated from the seed coat; (F) dorsal rib: cross-section through a vascular bundle with oil ducts (arrows); (G) marginal rib: crosssection through a vascular bundle; $(\mathrm{H})$ cross-sectional detail of the pericarp and seed with adhering oil ducts; (I) cross-section of the pericarp and seed - close-up of the oil ducts and pericarp cells with crystallized secretion 


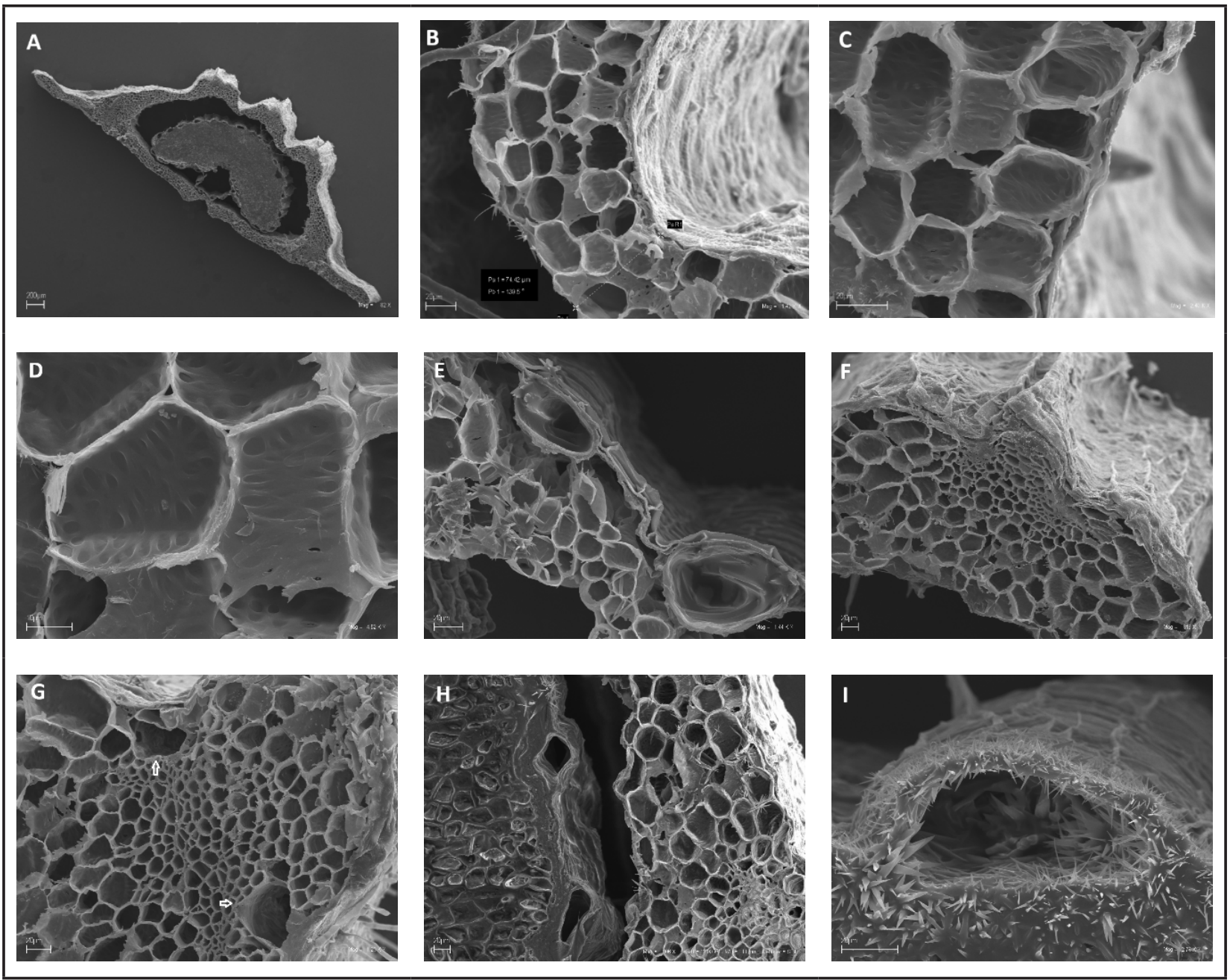

Figure 4.

SEM micrographs of fruits in Angelica archangelica subsp. litoralis (A) Cross-section of the mericarp - outermost part of the pericarp separated by an air cavity from the seed with the inner layer of the pericarp; (B) cross-section through the mesocarp and exocarp in the inter-rib depression; (C) cross-section of the pericarp: parenchyma cells of the mesocarp and hairs on the surface of epidermis; (D) parenchyma cells of the mesocarp with pitted walls; (E) cross-section of the layer of endocarp cells with paraendocarpic oil ducts; (F) cross-section through a dorsal rib with a vascular bundle; $(G)$ dorsal rib - cross-section through a vascular bundle with oil ducts (arrows); (H) cross-section with the visible portion of the endosperm, seed coat, oil ducts, and pericarp; (I) cross-sectional close-up of an oil duct with crystallized secretion

The endocarp consisted of a single layer of elongated cells and formed the inner boundary of the pericarp. It adhered to the seed on the dorsal side and was clearly separated from the seed coat on the commissural side (fig. 3E. 4E).

Numerous paraendocarpic secretory ducts, cyclically surrounding the seed were found (fig. 3A, 3E, $4 \mathrm{~A}, 4 \mathrm{E})$. In the fruits of Aaa, there were $35-46$ of them and they were located close to one another, whereas in the fruits of Aal there were 29-37 oil ducts and they were more sparsely distributed. The secretory ducts were elliptically shaped in the fruits of the typical subspecies, while in the coastal one they were elliptically compressed. In the fruits of Aaa, their width and height was $54.90-68.83 \mu \mathrm{m}$ and 40.91-49.97 $\mu \mathrm{m}$, respectively, whereas in the fruits of Aal the values of similar measurements were 63.08-92.21 $\mu \mathrm{m}$ and 38.81-43.45 $\mu \mathrm{m}$.

The seed coat was a compact layer of equal thickness surrounding an endosperm (fig. 3E, 4H). It was not possible to determine its detailed anatomical structure on SEM images.

The endosperm was kidney-shaped in crosssection, with a wide depression on the commissural 
side (fig. 3A, 4A). In cross-sectional view, the endosperm in Aaa was usually more deeply grooved than in Aal. The seed was filled with endosperm composed of tightly packed cells, rectangular or polygonal in outline (fig. $3 \mathrm{H}, 4 \mathrm{H}$ ).

Needle-like crystals were observed on the surface of the inner part of the mericarp. They were visible in large numbers in the cross-section of the fruit at the point of intersection of the secretory ducts, where at some places they formed massive concentrations in the opening of the ducts and in their vicinity (fig. 3I, 4I). These crystals were also found in some mesocarp cells of the pericarp.

\section{DISCUSSION}

Many characters encountered in the descriptions of related species of the family Apiaceae can be found in the carpological characteristics of Angelica.

The surface of the angelica fruits was wavy, with frequently inconspicuously outlined cell boundaries. Similar observations were made by Ostroumova - in the Angelica species investigated in her study, cells were visible only in some areas, whereas on the other surfaces of the fruits there were no clear cell boundaries [22]. The wing edge covered with isodiametric cells with raised edges of anticlinal walls and concave periclinal walls corresponds to the description characteristic of dorsally compressed fruits with a developed wing [22]. Radially striated cuticle around stomata is observed in some representatives of the family Apiaceae, e.g. Heracleum dissectum [22].

Research confirms that there is a relationship between morphological and anatomical characters and diaspore dispersal mode [21].

Angelica fruits are probably dispersed mainly with water - along rivers and coastal shores in the case of Aal, while in mountains with melting snow water and along streams, which is possible in the case of Aaa. The fruits can float on the water surface for a long time [7]. However, wind dispersal can also be found in the studied species $[5,40]$. The general structure of angelica fruits confirms such a possibility - dorsally compressed mericarps and winged marginal ribs are usually a characteristic feature of wind-dispersed fruits [37].

A detailed description of the fruit structure in Archangelica officinalis was given by Briquet who distinguished four primary mesocarp layers in young fruits: chlorenchyma, sculptured parenchyma, thin-walled cells of disaggregated mesocarp, and deep parenchyma [41]. As the fruit becomes ripe, parenchyma cells of the mesocarp become lignified, while the cell walls in this layer undergo disaggregation - they become ruptured.

In her study on the development of fruits in $\mathrm{An}$ gelica decurrens, Denisova noted that as a result of destruction of the disaggregation layer, an air bubble appears between the sculptured and deep parenchyma, which serves as a thermal insulator and reduces the fruit weight [42]. Furthermore, the large air-filled cavity allows mature mericarps to float on the water surface [7]. The seeds, together with the endocarp adhering to them, the paraendocarpic oil ducts, and the residue of the deep parenchyma of the mesocarp easily detach from other elements of the pericarp. While the fruit remains in water or moist soil, seeds are surrounded for a long time by a dense network of canals with essential oil having antibacterial and antifungal properties, protecting them against rotting [42]. Additional protection is provided by a continuous, thick seed coat. According to Zobel and March [43] the seed coat of A. archangelica is composed of an inner integument and much thinner outer integument. The verification of detailed anatomical structure of the seed coat of the examined taxa needs further histological studies.

In spite of the homogenous character of the structure type in the investigated angelica fruits, differences were also observed.

The presence of little excrescences on the surface of the cuticle in Aaa and the occurrence of hooked hairs in Aal can be stressed as characters of potential diagnostic significance. In Angelica decurrens, onecelled hairs occur only in young fruits. During the later stages of fruit development, only single, sporadically found trichomes remain on the epidermis [42]. In A. archangelica, on the other hand, at places hairs were observed in a larger number also in mature fruits.

Epicuticular secretions sometimes exhibit large variation within closely related species or even lower intraspecific categories. Among 11 species of the genus Angelica observed in SEM, only one of them, A. sachalinensis, was distinguished by the presence of wax platelets on the fruit surface [22]. In both $A$. archangelica species studied, epicuticular wax with numerous formations in the form of epicuticular wax plates and platelets occurred on the fruit surface. Nevertheless, the characters of the epidermis and wax plates found on its surface should be interpreted with great caution, similarly to all other taxonomic criteria [31]. One needs to remember that despite that they are undoubtedly genetically controlled, environmental conditions can also 
affected them [44-46]. The presence of hairs and the wax layer that surround the fruit protecting it against being soaked can certainly be regarded as an adaptation to dispersal by water.

In cross-section, the fruits of the studied taxa differed in the shape of their dorsal ribs - in Aaa they had a triangular outline, while in Aal a pentagonal one. These observations are in agreement with the morphological description of angelica fruits available in the literature where median ridges with a keeled edge in Aaa and median ridges with a rounded edge in Aal are reported as a characteristic feature [19].

The number of vittae is mentioned as one of the characteristic features in the anatomical structure of fruits which can serve as a reference in studying interspecific relationships [47]. As emphasized by Kljuykov et al., this number may vary in species of the genus Angelica [34]. The fruits of the studied subspecies differed in the number, width, and mode of distribution of paraendocarpic oil ducts; in the fruits of Aaa, their number was greater and they were located closer to one another, whereas in the fruits of Aal they were less numerous and less sparsely distributed than in the typical subspecies. In medial transverse section, the oil ducts were very numerous - in Aal up to 37 ducts were observed, most of them having a narrow elliptical opening, while in Aaa up to 46 ducts, predominantly with a wide elliptical shape. In the mericarps of the related species Angelica decurrens, up to 35 ducts were found [42].

Differences in mesocarp thickness were also found between the taxa investigated. Both the dorsal and commissural layers of the mesocarp were thicker in Aaa in comparison with Aal. Lignified cells with numerous pits in the cell walls observed in the mesocarp of angelica are quite common in dry fruits of Apiaceae and they are also encountered in some Angelica spp. [34, 22]. The layer of dead cells filled with air reduces the fruit mass and provides good thermal insulation of seeds [42]. This can explain the occurrence of a thicker mesocarp in the fruits of Aaa adapted to the mountainous environment, which are exposed to harsh habitat conditions - high temperature amplitudes, long-lasting snow or ice cover, and the presence of rocky substrate.

Needle-shaped crystals were found in the angelica fruits, particularly numerous in the inner part of the mericarp, in the surroundings of the seed coat, and at the place of intersection of the secretory ducts. A study by Zobel and March [43] regarding the location of furanocoumarins in tissues conducted using UV-induced autofluorescence may shed light on the origin and chemical nature of these crystals.
This study showed the presence of furanocoumarins in different parts of the fruit of $A$. archangelica. The highest concentration of these compounds was found in seed covers, but they were also present on the seed surface, whence they penetrated into the preparation solution. It is known that furanocoumarins can occur in plants in the form of crystals on the surface of the epidermis [48] or on the surface of the embryo [49]. As seen in SEM, in angelica the distribution of crystals on the surface of seeds and on adjacent tissues resembles the phenomenon of release of furanocoumarins into the surroundings which is recorded in UV light. This would indicate the organic origin of the observed crystals that probably correspond to crystallized secretion of glandular cells.

\section{CONCLUSIONS}

SEM examination of fruits is a valuable source of information regarding the intraspecific differentiation of $A$. archangelica and its adaptation to environmental conditions as well as it provides several new characters of potential taxonomic value.

The microsculpture of $A$. archangelica mericarps describes a set of characters characteristic for this species, such as the following: the presence of excrescences and hairs, the occurrence of cuticular striation and wax formations, but which also expand the description of the genus Angelica. Some of these characters, e.g. verrucose sculpture of the oil duct surface and the presence of hooked hairs, exhibit differentiation within the species.

Among the anatomical characters, the number and size of paraendocarpic oil ducts and the thickness of the dorsal and commissural mesocarp deserve special attention.

Further research on a larger sample is necessary to confirm the significance of the differences observed in the taxa in question.

Conflict of interest: Authors declare no conflict of interest.

\section{REFERENCES}

1. Rautio AM, Akselsson Linkowski W, Östlund L. They followed the power of the plant: historical sami harvest and traditional ecological knowledge (TEK) of Angelica archangelica in Northern Fennoscandia. J Ethnobiol 2016; 36(3):617-636. doi: http://dx.doi.org/10.2993/0278-0771-36.3.617 
2. Liao CY, Downie SR, Li Q, Yu Y, He X, Zhou B. New insights into the phylogeny of $A n$ gelica and its allies (Apiaceae) with emphasis on East Asian species, inferred from nrDNA, cpDNA, and morphological evidence. Syst Bot 2013; 38(1):266-281. doi: http://dx.doi. org/10.1600/036364413X662060

3. Downie SR, Spalik K, Katz-Downie DS, Reduron J-P. Major clades within Apiaceae subfamily Apioideae as inferred by phylogenetic analysis of nrDNA ITS sequences. Plant Divers Evol 2010; 128(1):111-136. doi: http://dx.doi.org/ 10.1127/1869-6155/2010/0128-0005

4. Feng T, Downie SR, Yu Y, Zhang X, Chen W, He X et al. Molecular systematics of Angelica and allied genera (Apiaceae) from the Hengduan Mountains of China based on nrDNA ITS sequences: phylogenetic affinities and biogeographic implications. J Plant Res 2009; 122(4):403-414. doi: http://dx.doi.org/10.1007/s10265-009-0238-4

5. Spalik K, Reduron JP, Downie S. The phylogenetic position of Peucedanum sensu lato and allied genera and their placement in tribe Selineae (Apiaceae, subfamily Apioideae). Plant Syst Evol 2004; 243:189-210. doi: https://dx.doi.org/10.1007/ s00606-003-0066-2

6. Meusel H, Jäger EJ, Bräutigam S, Knapp HD, Rauschert S, Weinert E. Vergleichende Chorologie der Zentraleuropäischen Flora. 3. Jena 1992 [in German].

7. Ojala A. Variation of Angelica archangelica ssp. archangelica (Apiaceae) in Northern Fennoscandia 1. Variation in Fruit Morphology. Ann Bot Fenn 1984; 21:103-15.

8. Weinert E. Die taxonomische Stellung und das Areal von Angelica archangelica L. und A. lucida L. Feddes Repert 1973; 84(4):303-314. doi: https://dx.doi.org/10.1002/fedr.19730840405

9. Thellung A. Umbelliferae. In: Hegi G (ed.). Illustrierte Flora von Mitteleuropa. München 1926; 5(2):926-1537.

10. Stroh P, Scott W. Angelica archangelica subsp. littoralis (Apiaceae) - a new native taxon for Britain. New J Bot 2017; 7(1):57-58. doi: https://dx.doi.org /10.1080/20423489.2017.1297353
11. Pyšek P, Sádlo J, Mandák B. Catalogue of alien plants of the Czech Republic. Preslia 2002; 74: 97186.

12. Keil P. Ökologie der gewässerbegleitenden Agriophyten Angelica archangelica ssp. litoralis, Bidens frondosa und Rorippa austriaca im Ruhrgebiet. [Ecology of the agriophytes Angelica archangelica ssp. litoralis, Bidens frondosa and Rorippa austriaca on river banks of the Ruhr region, Germany]. Dissert Bot 1999; 321:1-186.

13. Jackowiak B, Grabherr G. Zur Ausbreitung von Angelica archangelica L. an der Donau in Wien. Verh Zool-Bot Ges Österreich 1990; 127:113-122.

14. Jehlik V, Rostański K. Angelica archangelica subsp. litoralis auch in der Tschechoslowakei. Preslia 1975; 47(2):145-157.

15. Zając M, Zając A. Apophytes as invasive plants in the vegetation of Poland. Biodiv Res Conserv 2009; 15: 35-40. doi: http://dx.doi.org/10.2478/ v10119-009-0015-1

16. Zając A, Zając M. Distribution atlas of vascular plants in Poland. Kraków 2001.

17. Forycka A, Buchwald W. Variability of composition of essential oil and coumarin compounds of Angelica archangelica L. Herba Pol 2019; 65(4):62-75. doi: http://dx.doi.org/10.2478/hepo2019-0027

18. European Pharmacopoeia. $9^{\text {th }}$ Edition 9.0, 2016: 1242, Suppl. 9.8:1348.

19. Fröberg L. Angelica archangelica L. In: Jonsell B, Karlsson T (eds.). Flora Nordica 2010; 6:181-185.

20. Latowski K. Taksonomiczne i chorologiczne problemy $\mathrm{z}$ arcydzięglem. Taxonomic and chorological problems with Angelica archangelica. In: Olszewski TS, Afranowicz R, Bociąg K (eds.). Współczesne kierunki badań botanicznych. Ogólnopolska Konferencja Naukowa; 14-15 października, Gdańsk 2005:13-14 [in Polish].

21. Wojewódzka A, Baczyński J, Banasiak Ł, Downie SR, CzarnockaCieciura A, Gierek M, et al. Evolutionary shifts in fruit dispersal syndromes in Apiaceae tribe Scandiceae. Plant Syst Evol 2019; 305:401-414. https://dx.doi.org/10.1007/s00606019-01579-1 
22. Ostroumova TA. Fruit micromorphology in the Umbelliferae of the Russian Far East. Botanica Pacifica 2018; 7(1):41-49. doi: http://dx.doi. org/10.17581/bp.2018.07107

23. Morozowska M, Freitas MF, Luna BN, Toni KLGD. Comparative micromorphology and anatomy of seeds and endocarps of selected Primulaceae and their systematic implications. Plant Syst Evol 2020; 306:74. https://dx.doi. org/10.1007/s00606-020-01699-z

24. Ullah F, Papini A, Shah SN, Zaman W, Sohail A, Iqbal M. Seed micromorphology and its taxonomic evidence in subfamily Alsinoideae (Caryophyllaceae). Microsc Res Tech 2019; 82(3):250259. doi: http://dx.doi.org/10.1002/jemt.23167

25. Liu M, Downie SR. The phylogenetic significance of fruit anatomical and micromorphological structures in Chinese Heracleum species and related taxa (Apiaceae). Syst Bot 2017; 42(2):313-325. doi: http://dx.doi.org/10.1600/154823217X695539

26. Ostroumova TA, Kljuykov EV. Fruit structure and microsculpture in the annual species of the genus Bupleurum, section Perfoliata (Umbelliferae). Phytol Balc 2015; 21 (2):117-127.

27. Gamarra R, Ortúñez E, Galán Cela P, Guadaño V. Anacamptis versus Orchis (Orchidaceae): seed micromorphology and its taxonomic significance. Plant Syst Evol 2012; 298:597-607. doi: https:// dx.doi.org/10.1007/s00606-011-0569-1

28. Kahraman A, Ferhat Celep F, Dogan M, Guerin GR, Bagherpour S. Mericarp morphology and its systematic implications for the genus Salvia L. Section Hymenosphace Benth. (Lamiaceae) in Turkey. Plant Syst Evol 2011; 292(1):33-39. doi: http://dx.doi.org/10.1007/s00606-010-0394-y

29. Ostroumova TA, Pimenov MG, Ukrainskaja UA. Micromorphological diversity of hairs and emergences on fruits in the Umbelliferae and its taxonomic value. Bot Zhurn 2010; 95(9):1219-1231 [in Russian].

30. Szkudlarz P. Taxonomy of South African ericas (Erica L.) and differentiation of their seeds. Biodiv Res Conserv 2006; 1-2:25-30.

31. Barthlott W. Epidermal and seed surface characters of plants: systematic applicability and some evolutionary aspects. Nord J Bot 1981; 1:345-355.
32. Cutler DF, Brandham PE. Experimental evidence for the genetic control of leaf surface characters in hybrid Aloineae (Liliaceae). Kew Bull 1977; 32:2332.

33. Karcz J. Skaningowy mikroskop elektronowy w badaniach karpologicznych. Scanning electron microscope in carpological studies. Wiad Bot 1996; 40(3/4):55-65 [in Polish].

34. Kljuykov EV, Zakharova EA, Ostroumova TA, Tilney PM. Most important carpological anatomical characters in the taxonomy of Apiaceae. Bot J Linn Soc 2020; 20:1-13.

35. Pimenov MG, Ostroumova TA. Carpological characters in the Umbelliferae systematics. In: Lotova LI, Timonin AC (eds.). Kaden's memorial book. Moscow 2014:158-172 [in Russian].

36. Klimko M, Truchan M, Wysakowska I. Fruit and seed morphology of the genus Heracleum L. (Apiaceae) in Poland. Bot - Stec 2013; 17:13-24.

37. Liu MR, Plunkett GM, Lowry PP, Van Wyk $\mathrm{BE}$, Tilney PM. The taxonomic value of fruit wing types in the order Apiales. Am J Bot 2006; 93(9):1357-1368.

38. Kljuykov EV, Liu M, Ostroumova TA, Pimenov MG, Tilney PM, van Wyk BE. Towards a standardised terminology for taxonomically important morphological characters in the Umbelliferae. S Afr J Bot 2004; 70:488-496.

39. Barthlott W, Neinhuis C, Cutler D, Ditsch F, Meusel I, Theisen I et al. Classification and terminology of plant epicuticular waxes. Bot J Linn Soc 1998; 126(3):237-260. doi: https://dx. doi. org/10.1111/j.1095-8339.1998.tb02529.x

40. Jongejans E, Telenius A. Field experiments on seed dispersal by wind in ten umbelliferous species (Apiaceae). Plant Ecol 2001; 152:67-78.

41. Briquet J. Carpologie comparée de l'Archangelica officinalis Hoffm. et Peucedanum palustre (L.). Moench. Candollea 1923; 1:501-520.

42. Denisova GA. The development of the fruit of Archangelica decurrens Ldb. Bot Zhurn S.S.S.R 1961; 46(12): 1756-1765 [in Russian]

43. Zobel AL, March RE. Autofluorescence reveals different histological localizations of furanocou- 
marins in fruits of some Umbelliferae and Leguminosae. Ann Bot 1993; 71:251-255.

44. Zieliński J, Tomaszewski D, Gawlak M, Orlova L. Kłopotliwe derenie - Cornus alba L. i C. sericea L. (Cornaceae). Dwa gatunki czy jeden? Troublesome dogwoods - Cornus alba L. and C. sericea L. (Cornaceae). Two species or one? Rocznik PTD 2014; 62:9-23 [in Polish].

45. Shepherd T, Robertson GW, Griffiths DW, Birch ANE, Duncan G. Effects of environment on the composition of epicuticular wax from kale and swede. Phytochemistry 1995; 40(2):407-417. doi: https://dx.doi.org/10.1016/0031-9422(95)00281-b

46. Huttunen S. Effects of air pollutants on epicuticular wax structure. In: Percy KE, Cape J, Jagels R, Simpson CJ (eds.). Air pollutants and the leaf cuticle. Berlin Heidelberg 1994:81-96. doi: http:// dx.doi.org/10.1007/978-3-642-79081-2_6
47. Zhang Q-Y, He X-J, Zhang Y-Ch. Anatomical studies on fruits and petioles of 8 species of $A n$ gelica L. from Sichuan Province. Plant Sci J 2005; 23(6):549-554.

48. Bruni R, Barreca D, Protti M, Brighenti V, Righetti L, Anceschi L, et al. Botanical sources, chemistry, analysis, and biological activity of furanocoumarins of pharmaceutical interest. Molecules 2019; 24(11):2163. doi: http://dx.doi.org/10.3390/molecules 24112163

49. Zobel AM, Brown SA, March RE. Histological localization of psoralens in fruits of Psoralea bituminosa. Can J Botany 1991; 69(8):1673-1678. 